\title{
RECEPTIVENESS OF THE STIGMA AND IN VITRO GERMINATION OF ORANGE POLLEN, SUBMITTED TO DIFFERENT TEMPERATURES
}

\author{
Receptividade do estigma e germinação in vitro do \\ pólen de laranjas submetido a diferentes temperaturas \\ Leila Aparecida Salles Pio', José Darlan Ramos², \\ Moacir Pasqual' ${ }^{2}$, Flavia Carvalho Santos ${ }^{3}$, Keize Pereira Junqueira ${ }^{3}$
}

\begin{abstract}
The study was carried out in order to evaluate the effect of temperature and in vitor stigma receptivity on regeneration of orange cultivar (Valência, Pêra and Natal) pollen. Two experiments were carried out, in the first the ideal temperature of germination was assessed. Pollen was obtained from flowers at the balloon stage and inoculated in culture medium with $10 \mathrm{~g} \mathrm{~L}^{-1}$ agar, $200 \mathrm{mg} \mathrm{L}^{-1}$ boric acid, $100 \mathrm{~g} \mathrm{~L}^{-1}$ sucrose, $800 \mathrm{mg} \mathrm{L}^{-1}$ calcium nitrate, $\mathrm{pH}$ adjusted to 6,5 and incubated in a BOD chamber at temperatures of $23,24,25,26$ and $27^{\circ} \mathrm{C}$ during a 24-hour photoperiod. After 12 hours of incubation, the best temperature for pollen grain germination was $25^{\circ} \mathrm{C}$ for all varieties. In a second experiment, in order to test the receptivity of the stigma, flowers were collected at different flowering stages: small bud, balloon and open flower. The stigmas were by immersion exposed to hydrogen peroxide (perioxidase reaction), $3 \%$ for 3 minutes. Through the technique of Zeisler (1938), better results were detected at the balloon stage with 80 to $100 \%$ receptivity, while for the open flower the receptivity presented maximum indexes.
\end{abstract}

Index terms: Citrus sinensis, Palinology, tissue culture.

\section{RESUMO}

Objetivou-se determinar a melhor temperatura para a germinação de grãos de pólen e avaliar a receptividade do estigma das cultivares cítricas Valência, Pêra e Natal. Para avaliar a temperatura ideal de germinação, grãos de pólen foram obtidos de flores em estágio "balão" e inoculados em meio de cultura constituído por $10 \mathrm{~g} \mathrm{~L}^{-1} \mathrm{de}$ ágar, $200 \mathrm{mg} \mathrm{L}^{-1}$ de ácido bórico, $100 \mathrm{~g} \mathrm{~L}^{-1}$ de sacarose, $800 \mathrm{mg} \mathrm{L}^{-1}$ de nitrato de cálcio, $\mathrm{pH}$ ajustado para 6,5 e incubado nas temperaturas de $23,24,25,26$ e $27^{\circ} \mathrm{C}$ em estufa tipo D.B.O. e fotoperíodo constante de 24 horas. Após 12 horas de incubação, observou-se que a melhor temperatura de germinação de grãos de pólen é de $25^{\circ} \mathrm{C}$ para todas as variedades. Para avaliar a receptividade do estigma, foram coletadas flores em diferentes estádios de florescimento: botão pequeno, balão e flor aberta. Os estigmas foram retirados e imersos em água oxigenada a 3\% por 3 minutos. A liberação de bolhas de ar indica que o estigma está receptivo. Melhores resultados foram obtidos com a técnica de Zeisler (1938), no estágio de balão com 80 a 100\% de receptividade, ao passo que a receptividade para a flor aberta apresentou os índices máximos.

Termos para indexação: Citrus sinensis, Palinologia, Cultura de tecidos.

(Recebido para publicação em 3 de outubro de 2003 e aprovado em 1ํ de junho de 2004)

\section{INTRODUCTION}

Brazil is the first world producer of citric fruits. Orange production, mainly for the concentrated and frozen orange juice industry (SLCC) has always been greater compared to the other citrus varieties. In breeding programs for this species, manual pollination is normally carried out in the field. To perform this work, it is necessary to know whether the stigma is receptive at the moment of this pollination.
For successful pollination, the pollen must be transferred to the stigma at the moment that it is receptive. In some cases, the pollen is deposited before the receptive period; and the pollen should remain viable for a period long enough to germinate (STÖSSER et al., 1997). For this to happen the period of receptiveness of the stigma must be known, but in many cases it is easily determined (THOMPSON and BARRET, 1981).

\footnotetext{
1. Engenheira Agrônoma, mestranda em Fitotecnia, Departamento de Agricultura da Universidade Federal de Lavras/UFLA - Caixa Postal 3037 - $37200-000$ Lavras, MG. leilapio@ufla.br

2. Professor, Doutor, DAG/UFLA.

3. Acadêmica do curso de Agronomia - UFLA.
} 
Chemical tests have been developed to determine the stigma receptiveness and one nvolves the enzymatic reactions of the peroxidase enzyme, based on the hypothesis that the presence of this enzyme reflects in the receptiveness of the stigma (GALEN et al., 1985). The test is based on staining the stigma with hydrogen peroxide (peroxide water), if the peroxidase enzyme is present many oxygen bubbles form, released by the chemical reaction of the peroxide with the enzyme.

Several studies using the enzyme method to assess the stigma receptiveness were found in the literature. JAWALE et al. (1999) reported that stigma receptiveness in sunflower lasted from 22 hours to three days. JAWALE et al. (1990) studied the garden rose and detected that stigma receptiveness was very low on the first day when the flower opened, and reached maximum between the 4th and 6th day after the flower opened, depending on the cultivar. In quinces, the stigma receptiveness was $19.99 \%$ one day before anthesis, $34.99 \%$ on the day of anthesis and $12.49 \%$ one day after anthesis (SINGH and SIRIVASTAVA, 2000). Harikarunakar and Haripriya (2000) reported that onion stigmas were receptive for six days after anthesis. The same authors observed that the stigma receptiveness in pomegranate varied from two days before to six days after anthesis. No studies on receptiveness in citrus stigma were found.

Several studies have been performed to determine quantitatively and qualitatively the components necessary for the best composition of culture medium in pollen grain germination. However, temperature is another very important factor in the control of the environmental conditions and influences pollen grain germination significantly (Pio, 2002).

Pinus poderosa germination was observed after eight days at $3^{\circ} \mathrm{C}$, while at $15^{\circ} \mathrm{C}$ it germinated in two days and at $30^{\circ} \mathrm{C}$ it began to germinate in six hours (WORSLEY, 1959). However, Dorman (1976) observed, in studies on Pinus, that temperatures between 25 and $26^{\circ} \mathrm{C}$ were more indicated for pollen germination. The temperatures of $25^{\circ} \mathrm{C}$ and $30^{\circ} \mathrm{C}$ would be more suitable for germination of various Eucalyptus species (Boden,1958).

Silva (1996) studied different temperatures for passion fruit pollen germination, $20,24,25$ and $28^{\circ} \mathrm{C}$ and obtained best results at $28^{\circ} \mathrm{C}$. Ruggiero et al. (1976) observed that yellow passion fruit pollen grains kept at 24 and $25^{\circ} \mathrm{C}$ began germination 30 minutes after placing in the artificial medium and six hours afterwards there was no more pollen tube formation.

When assessing pear tree (Pyrus communis) pollen, Vasilakakis and Porling (1985) observed a reduction in germination below $15^{\circ} \mathrm{C}$, while the growth rate of the in vitro pollen increased when the temperature was between 5 and $25^{\circ} \mathrm{C}$.

Rosell et al. (1999) observed that the optimum temperature for cherimoya (Annona squamosa) pollen grain germination ranged from 20 to $25^{\circ} \mathrm{C}$. In experiments performed with kiwi (Actinidia chinensis) pollen grains, Boden (1958) observed that the ideal temperature was $27^{\circ} \mathrm{C}$. Tuinstra and Wendel studied sorghum (Sorghum bicolor), and reported that pollen germination was not affected in the interval between 20 and $40^{\circ} \mathrm{C}$, but germination was significantly reduced at $10^{\circ} \mathrm{C}$. No report was found in the literature regarding temperature for citrus pollen grain germination.

The objective of this study was to determine the best temperature for pollen grain germination and stigma receptiveness in the citrus cultivars Valência, Pêra and Natal.

\section{MATERIAL AND METHODS}

To carry out the stigma receptiveness experiment, flowers were collected at different stages of flowering: small buds (less than $1 \mathrm{~cm}$ ), balloon (larger than $1 \mathrm{~cm}$ ) and recently opened flowers, of the orange tree cultivars Valência, Pêra and Natal, in the orchard at EPAMIG, Lavras-MG. The collection was made in September 2002, from five-year-old plants. Fifty flowers were collected, at each stage, in all the quadrants of the plant, using two plants for each variety.

The flowers were taken to the Plant Tissue Culture Laboratory at the Department of Agriculture, UFLA, to detect the receptiveness of the stigma. The flower structures were removed, leaving only the stigma that was immersed in a solution with oxygenated water at $3 \%$ for three minutes, following the technique described by Zeisler (1938). By this technique, the direct action of the oxygenated water with the enzyme present is detected in the receptive stigmas. The release of oxygen bubbles indicates that the stigma is receptive. The size, color and presence of droplets was also observed on the upper part of the stigma and the permanence of pollen on it. 
In the experiment to assess the best germination temperature, a completely randomized block design was used, consisting of four replications, and each replication was represented by one Petri dish and 100 pollen grains counted per replication, with the help of an optical microscope with a 10x lens. Pollen grains were considered germinated whose pollen tube length was greater than the diameter of the pollen grains.

The cultivars used where the same as in the previous experiment. Flowers were collected at the balloon stage and taken to the Tissue Culture Laboratory where the anthers were removed and placed on petri dishes with filter paper and kept at $26^{\circ} \mathrm{C}$ for 24 hours to complete the dehiscence. The culture medium used for germination was $10 \mathrm{~g} \mathrm{~L}^{-1}$ agar, $200 \mathrm{mg} \mathrm{L}^{-1}$ boric acid, $100 \mathrm{~g} \mathrm{~L}^{-1}$ sucrose, 800 $\mathrm{mg} \mathrm{\textrm {L } ^ { - 1 }}$ calcium nitrate and $\mathrm{pH}$ adjusted to 6.5 , Pio (2003). The culture medium was heated in a microwave oven to $95^{\circ} \mathrm{C}$, then $10 \mathrm{ml}$ was poured on to a Petri dish. The pollen from each cultivar was sprinkled on the surface of the culture medium using a paint brush, so the material was uniformly distributed. The temperatures of $23,24,25,26^{\circ} \mathrm{C}$ were tested, obtained in a BOD chamber with a 12 hour light period.

After 12 hours incubation, the percentage of germinated pollen grains was counted. The data observed were submitted to statistical analysis using the Sisvar software.

\section{RESULTS AND DISCUSSION}

At the balloon stage, 80 to $100 \%$ of the flowers were receptive, observed by the presence of bubbling verified visually after contact of the stigma with oxygenated water, indicating the presence of the enzyme. This value was $100 \%$ For the open flowers. The small buds did not show receptiveness (Table 1).

For successful fertilization, it is desirable that the pollen is transferred to the receptive stigma of another flower. In many cases, fertilization can occur when the pollen grain is deposited before the receptive period as long as it remains viable long enough to be able to germinate as soon as the flower becomes receptive (THOMSON AND BARRET, 1981).
TABLE 1 - Percentage of receptiveness of the stigma in flowers of citric varieties in three stages of development. UFLA, Lavras, 2002.

\begin{tabular}{lccc}
\hline Cultivars & $\begin{array}{c}\text { Small Bud } \\
(\boldsymbol{\%})\end{array}$ & $\begin{array}{c}\text { Balloon Bud } \\
(\boldsymbol{\%})\end{array}$ & $\begin{array}{c}\text { Open Flower } \\
(\boldsymbol{\%})\end{array}$ \\
\hline Natal & 0 & 80 & 100 \\
\hline Valência & 0 & 100 & 100 \\
\hline Pêra & 0 & 100 & 100 \\
\hline
\end{tabular}

Mean of 50 flowers analyzed for each treatment.

The enzymatic activity of the peroxidase, in this study, was greater in open flowers, and can increase fertilization success. The flowers at the balloon stage also presented activity of this enzyme. This data is important for the breeder, because it allows him to make the crossings in this phase, when the flowers do not need to be bagged to prevent previous contamination by undesired pollen. The index of self pollination at this phase is not significant, because the anthesis occurs only after flower opening.

Table 3 shows the table of analysis of variance for the factors studied, variety and germination temperature of pollen grains. There was a significant effect for variety in temperature at the level of $1 \%$ probability, and there was no interaction among the factors studied.

In Figure 1A, the best percentage of germinated pollen grains $(11.7 \%)$ was obtained with the Valencia cultivar. The other cultivars, Pêra and Natal, presented significantly inferior results. This difference among the varieties studied is related to the differences in their genotypes.

These results are in line with those reported by Vasilakakis and Porling (1985), who obtained greater indices of pollen tube growth at $25^{\circ} \mathrm{C}$, in studies carried out with Pêra orange tree pollen.

The optimum temperature for citrus pollen grain germination was $25^{\circ} \mathrm{C}$, similar to most of the species quoted in the literature, where the best germination indices occur in the interval of 20 to $30^{\circ} \mathrm{C}$. (FARMER JÚNIOR and HALL, 1974; RUGGIERO et al., 1976; VASILAKAKIS and PORLING, 1985). 
TABLE 2 - Stigma characteristics in flowers of the Valência, Pêra and Natal varieties at three stages of development. UFLA, Lavras, 2002.

\begin{tabular}{lccc}
\hline \multicolumn{1}{c}{ Parâmetros } & Botão Small & Botão balão & Flor Aberta \\
\hline Size & Small & medium & large \\
\hline Color & Dark green & Greenish-yellow & yellow \\
\hline Presence of droplets & absent & present & present \\
\hline Permanence of pollen on the surface & absent & permanent & permanent
\end{tabular}

\section{Mean of 50 flowers analyzed for each treatment.}
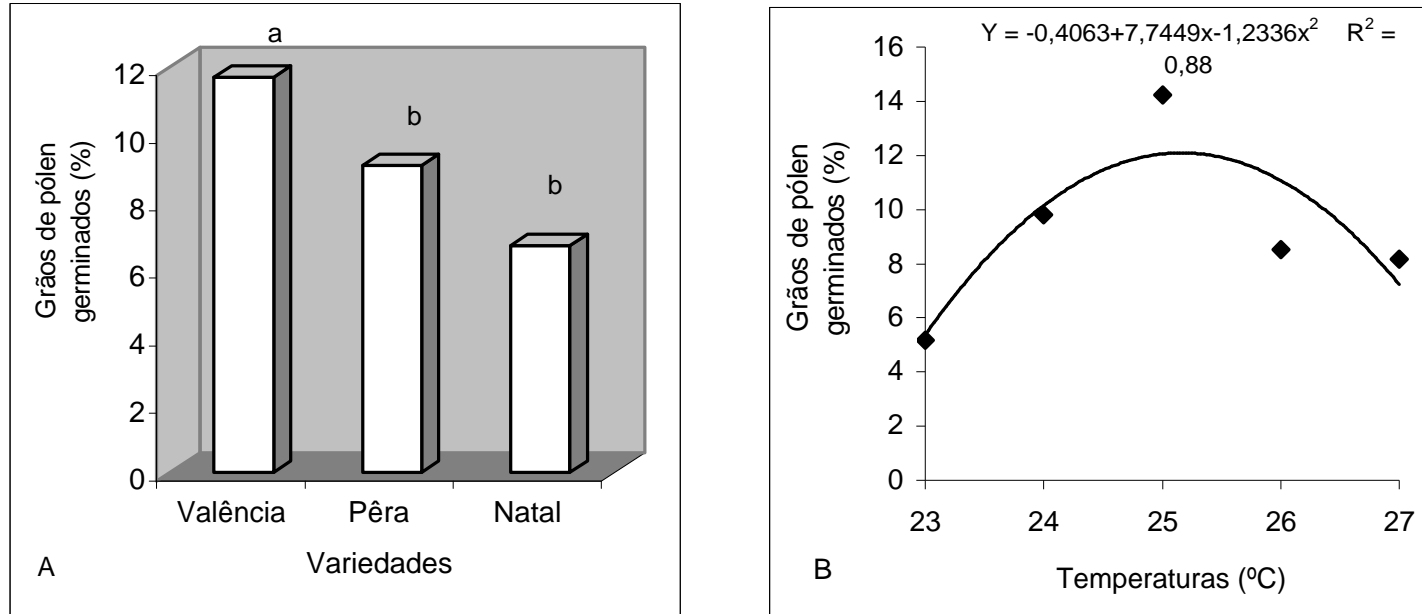

FIGURE 1 - Mean of germinated pollen grains of the orange tree cultivars (1A) presented and percentage of germinated pollen grains of the orange tree cultivars when submitted to different temperatures (1B). UFLA, Lavras, 2002

TABLE 3 - Analysis of variance for the variable germinated pollen grains of different citrus cultivars submitted to various temperatures. Lavras - MG 2003.

\begin{tabular}{lcc}
\hline \multirow{2}{*}{ Causes of variation } & GL & Mean square \\
\cline { 2 - 3 } & & Germinated (\%) \\
\hline Cultivars & 3 & $109.994^{* *}$ \\
\hline Temperatures & 5 & $120.661^{* *}$ \\
\hline Var. X Temp. & 7 & $0,354 \mathrm{~ns}$ \\
\hline Residue & 44 & \\
\hline C.V. $(\%)$ & & 24,68 \\
\hline General Mean $(\%)$ & & 9,178 \\
\hline
\end{tabular}

\section{CONCLUSION}

For the Valencia and Pêra cultivars, manual pollination can be performed at the balloon stage. For the Natal cultivar, receptivity was greater in open flowers.

The greater percentage of pollen grain germination was obtained at $25^{\circ} \mathrm{C}$ for all the cultivars tested. The Valencia cultivar presented a greater percent of germinated pollen grains.

\section{REFERENCES}

BODEN, R. W. Handling and storage of pollen in Eucalyptus breeding. Australian Forestry, Camberra, v. 12 , n. 2, p. 73-81, 1958. 
DORMAN, K. W. The genetics and breeding of southern pines. Washington: USDA, 1976. 407 p.

FARMER JÚNIOR, R. E.; HALL, G. C. In vitro testing and long-term storage of black cherry pollen. In: NORTHEASTERN FOREST TREE IMPROVEMENT CONFERENCE, 22., 1974, Syracuse. Proceedings... Syracuse: USDA/NE, 1974. p. 19-22.

GALEN, C.; PLOWRIGHT, R. C.; THOMPSON, J. D. Floral biologyand regulation of seed set and size in the lily, Clintonia borealis. American Journal of Botany, Columbus, v. 72, n. 10, p. 1544-1552, 1985.

HARIKARUNAKAR， D.; HARIPRIYA，K. Floral biology of aggregatum onion (Allium cepa var. aggregatum). Madras Agricultural Journal, Chidambaram, v. 86, n. 1-3, p. 166-169, 2000.

JAWALE, L. N.; SUDEWAD, S. M.; BARURE, D. T.; MAHAJAN, R. C. Studies on stigma receptivity and pollen viability in sunflower. Journal of Maharashtra Agricultural Universities, Parbhani, v. 23, n. 3, p. 312, 1999.

PIO, L. A. S. Viabilidade do pólen de citros em diferentes condições de armazenamento. 2003. 45 p. Dissertação (Mestrado em Fitotecnia) - Universidade Federal de Lavras, Lavras, 2003.

ROSELL, P.; HERRERO, M.; GALAN-SAUCO, V. Pollen germination of cherimoya (Annona cherimola Mill.): in vivo characterization and optimization of in vitro germination. Scientia-Horticulturae, Tenerife, v. 81, n. 3, p. 251-265, 1999

RUGGIERO, C.; LAN SANCHEZ; MIGUEL, S. Estudo sobre a fertilidade de grãos de pólen de maracujá amarelo (Passiflora edulis f. flavicarpa Deg.) In: CONGRESSO BRASILEIRO DE FRUTICULTURA, 3., 1975, Rio de Janeiro, RJ. Anais... Campinas: Sociedade Brasileira de Fruticultura, 1976. v. 2, p. 515-519.

SILVA, M. M. da. Influência das abelhas na polinização e de agrotóxicos na germinação de pólen do maracujazeiro (Passiflora edulis f. flavicarpa Deg.). 1996. 59 f. Dissertação (Mestrado em Fitotecnia) - Universidade Federal de Viçosa, Viçosa, 1996.

SINGH, H. K.; SRIVASTAVA, K. K. Floral biology of bael (Aegle marmelos) cultivars. Indian Journal of Agricultural Sciences, Faizabad, v. 70, n. 11, p. 797 798, 2000.

STÖSSER, R.; HARTMAN, W.; ANVARY, S. F. General aspects of pollination and fertilization of pome and stone fruit. Acta Horticulturae, Wageningen, v. 423, 1997.

THOMSOM, J. D.; BARRET, S. C. H. Temporal variation of gender in Aralia hispida Vent. (Araliaceae). Evolution, Lawrence, v. 35, n. 6, p. 1094-1107, 1981.

VASILAKAKIS, M.; PORLING, I. C. Effect of temperature on pollen germination, pollen tube growth, effective pollination period, and fruit set of pear. Hort Science, Saint Joseph, v. 20, n. 4, p. 733-735, 1985.

WORSLEY, R. G. F. The processing of pollen. Silva \& Genetics, Frankfurt, v. 8, n. 5, p. 143-148, 1959.

ZEISLER, M. Über die Abgrenzung der eigentlichen Narbenfläche mit Hilfe von Reaktionen. Beihefte zum Botanisches Zentralblatta, Berlin, v. 58, p. 308-318, 1938. 